\title{
Effects of Foreign Direct Investment on GDP: Empirical Evidence from Developing Country
}

\author{
Arafatur Rahaman ${ }^{1, *}$, Sumit Chakraborty ${ }^{2}$ \\ ${ }^{1}$ School of Business Studies, Southeast University, Bangladesh \\ ${ }^{2}$ Ahsanullah University of Science \& Technology, Bangladesh
}

Copyright (C) 2015 by authors, all rights reserved. Authors agree that this article remains permanently open access under the terms of the Creative Commons Attribution License 4.0 International License

\begin{abstract}
This empirical research is to analyze the causal relationship between foreign direct investment (FDI) and gross domestic product (GDP) mainly focused on Bangladesh. The main objective of the paper is to investigate existence and nature of the effect of FDI on GDP in Bangladesh from the perspective of developing country. The researcher applies cointegration test that confirmed the existence of long-run equilibrium relationship and Granger causality test assured the presence of uni-directional causality which runs from foreign direct investment to GDP. Findings of the study concluded that comparing to neighbour Asian countries FDI inflow is very low and Bangladesh should develop infrastructure, skill labor, shortage of power and electricity generation, investment friendly macroeconomic framework \& also political stability to attract foreign investors significantly.
\end{abstract}

Keywords Foreign Direct Investment (FDI), Gross Domestic Product (GDP), Cointegration, Granger Causality

\section{Introduction}

Foreign direct investment (FDI) is investment directly into production in a country by a company located in another country, either by buying a company in the target country or by expanding operations of an existing business in that country. Foreign direct investment is done for many reasons including to take advantage of cheaper wages in the country, special investment privileges such as tax exemptions offered by the country as an incentive to gain tariff-free access to the markets of the country or the region. In developing countries, foreign direct investment (FDI) is known as an important catalyst for economic growth. By transferring technology, increasing human capital formulation, access to global market and also stimulating domestic investment \& affects economic growth of host countries'.

Most emerging economies are now considering FDI as an integral source of growth, but so far growth has been unable to either forecast or even measure accurately the economic impact of foreign direct investment (FDI). Developing countries are not unaware of the advantages of FDI. Therefore, these countries usually compete with each other to attract FDI inflow through applying various attractive policies for foreign investors (Mottalab 2007) ${ }^{[1]}$. Many researchers have proven the function of FDI in the growth of economies, through its role in HR development, technological transmission; capital construction as well as international trade Borensztein, et al. (1998) ${ }^{[2]}$ through a study of 69 developing countries confirm that the LDCs do benefit from FDI, if they have the capabilities to absorb advanced technologies.

Even though some studies show that, FDI and trade have a positive impact on economic growth, the size of such impact may vary across countries depending on the level of human capital, domestic investment, infrastructure, macroeconomic stability, and trade policies. The literature continues to debate the role of FDI and trade in economic growth as well as the importance of economic and institutional developments in fostering FDI and trade. The lack of consensus limits our understanding of the role FDI and trade policies in economic growth process and restricts our ability to develop policies to promote economic growth

There are few issues which have long been debated and have not been resolved in the literature of development economics. The causal link of foreign direct investment (FDI) is one of them. There are findings which support that FDI tends to promote economic growth. FDI provides essential ingredients that are necessary for economic growth. By providing new production process, techniques, managerial skills and new varieties of capital goods, FDI promotes the economic growth of the less developed countries (LDC). The transfer of new techniques and technology spillover from the subsidiaries of multinational to domestic firms and enhances economic growth. On the other hand, others found that FDI follows economic growth. Economic growth first provides necessary and conducive economic factors for FDI to play a positive role for economic development. For example, the spillover effect of technology transfer although FDI can only 
be successful if the absorbing capacity of host countries is developed.

Bangladesh has been turning into the most generous FDI recipient in south Asia despite having a number of impediments, such as poor infrastructure, scarcity of power supply, political instability, rebaptism of bureaucrats, poor law and order situation etc. However, cheapest labour cost, tax holiday facilities etc have been able to make the country a centre of attention of the overseas investors. Until the 1980s, Bangladesh was skeptical of the intentions of FDI and considered it as tools for promoting an interest. The board of investment of Bangladesh has been playing a significant role to make Bangladesh the most favorable FDI region by offering convenient facilities and promotion of investments to the overseas investors.

This study is a modest attempt to examine the empirical relationship between FDI and economic growth in Bangladesh from 1987 to 2011 . The main focus of this study lies in analyzing the behavior of some selected macroeconomic indicators accompanying the surge in inflows of foreign direct investment in Bangladesh since 1987 the year in which the inflows started entering on a significant scale. The econometric methodology used in this study is time series analyses, with bi-variate regression and Granger causality test. These techniques allow us to capture the short-term and long-term effects of FDI inflows. Data on the relevant variables between years 1987 to 2011 is used for the study.

\section{Literature Review}

During the last two decades, a large number of studies focused on the role of FDI in stimulating economic growth in the LDC. But there is no consensus with regard to the direction of causality. Foreign Direct Investment (FDI) is very important for developing countries. Though foreign direct investment, individuals or corporation obtain partial or total ownership of firms located in another country. But the foreign investor should have lasting interest and substantial control over the investment. FDI contribute to growth through several channels. It directly affects growth through being a source of capital formation. As a part of the private investment, an increase in FDI will, by itself, contribute to an increase in total investment. An increase in investment directly contributes to growth. A large number of studies have been done in the field of foreign direct investment and economic growth. Some of the major studies are reviewed and discussed below.

Bloomstorm, Lipsey and Zejan (1996) ${ }^{[3]}$ found evidence that FDI Granger caused economic growth. However, FDI's positive conditional. According to them, FDI is growth enhancing if the country is sufficiently measured in terms of high per capita income. Caves (1996) ${ }^{[4]}$ found the bidirectional relationship. FDI and economic growth are positively interdependent. Large economic growth provides high-profit opportunities attracting higher domestic and foreign direct investments. On the other hand, FDI through its spillover effect has direct positive economic growth of host countries.

Borensztein et.al (1998) examine the effect of the foreign direct investment on economic growth in the cross-country regression framework, utilizing data on FDI flows from industrial countries to 69 developing countries over the last two decades. Their income of this study is that FDI is an important vehicle for the transfer of technology, contributing relatively more to growth than domestic investment. However, the higher productivity of FDI holds only when the host country has a minimum threshold stock of human capital. Thus, FDI contributes to economic growth only when a sufficient absorptive capability of the advanced technologies is available in the host economy.

Carkovic and Levine (2002) ${ }^{[5]}$ examined the effect of FDI on economic growth and concluded that FDI had no impact on long-term economic growth. They used a panel data set covering 72 developed countries in order to analyze the relationship between FDI inflows and economic growth. They argued that the lack of positive impact of FDI on economic growth is not conditional upon human capital, the level of economic development or openness of the economy. As developed financial intermediary system will lead to better resource allocation which accelerate the productivity growth and cause growth in the economy (Bech, Levine \& Loayza (2000) ${ }^{[6]}$

There is a further study done by Chowdhury and Mavrotas (2003) ${ }^{[7]}$ which examine the causal relationship between FDI and economic growth by using an innovative econometric methodology to study the direction of causality between the two variables. The study involves time series data covering the period from 1969 to 2000 for three developing countries, namely Chile, Malaysia and Thailand, all of them the major recipient of FDI with a different history of macroeconomic episodes, policy regime and growth patterns. Kholdy and Sohrabian (2005) ${ }^{[8]}$ found no causal link between economic growths. Thus, the empirical evidence on the causal link between FDI and economic growth is mixed that deserves the fresh enquiry into this issue. Hsio and Shen (2003) ${ }^{[9]}$ argue the two-way relationship between FDI and growth and support feedback relationship between FDI and GDP. Using a panel data on 84 countries covering the period of 30 years from 1970-1999.

Economic growth is affected by domestic investment, the more the domestic investment the more is employment opportunities and finally leads towards the growth in the economy. Other factors that also promote economic growth are development in the financial sector, financial openness and remittance. The factors that inversely affect the economic growth are an increase in the inflation rate and trade openness (Shabazz, Ahmed \& AR Chaudhary (2008) [10]. Economic growth can also be achieved through establishing a sound financial intermediary system.

According to the findings of Choe (2003) ${ }^{[11]}$, causing between economic growth and FDI runs in either direction but with a tendency towards growth causing FDI; there is 
little evidence that FDI causes host country growth. Rapid economic growth could result in an increase in FDI inflows. By using Granger causality test reported a positive significant relationship between FDI and economic growth in 80 countries. But this relationship was more prominent from economic growth to FDI rather than from FDI to growth. However, some researchers exhibit the different point of view regarding the relationship Reichert and Weinhold (2001) ${ }^{[12]}$ documented that although a causal relationship has been found between FDI economic growths but with high heterogeneity across countries. FDI performed better in open economies. Likewise, FDI showed a high effectiveness in enhancing growth of forty-six developing countries economy which were following more export-promoting policies than import substituting policies. Balasubramanyam et al (1999) ${ }^{[13]}$ analysed how FDI affect economic growth in developing countries. Using cross-section data and OLS regression he finds that FDI has a positive effect on economic growth in host countries using an export promoting strategy but not in countries using an import substitution strategy.

Empirical findings have so far not offered clear-cut conclusion with respect to the causality between FDI and growth. The surge of FDI might be associated with domestic policy variables. De Mello finds that FDI plays a determinant role in increasing both output and Total Factor Productivity (TFP) in Chile while capital accumulation and TFP growth precede FDI in Brazil. In both cases, the direction of the relevant causalities cannot be determined. The direction of causality between FDI and growth may well depend on the determinants of FDI. If the determinants have strong links with growth in the host country, growth may be found to cause FDI while the output may grow faster when FDI takes place in other circumstances (De Mello, 1997) ${ }^{[14]}$.

Finally, we can observe that several studies are focused on the case of developing countries and the major part of them stress that FDI, adjusted to other determinants, have a significant positive effect on economic growth. Several of these studies used time series regression, and panel data analysis to establish the link between FDI and growth. Many of the previous studies used per capita GDP as a substitution for growth, but FDI mainly effects on the income of labour force. So using overall GDP of the country would show the better result. The main conclusions show that FDI inflows exert a positive impact on economic growth only in the presence of highly skilled labour. The economies of various countries have gone through the phase of structural discontinuity because of many global events like the oil shock, stock market crisis, currency crisis etc.

\section{Methodology \& Specification of Model}

This research is conducted based on secondary data collected from World Investment Report (WIR), World Bank statistics, Bangladesh govt. fiscal year budget
(1987-2011) and different published journals. The main objective of this research is to examine the effect of foreign direct investment (FDI) on gross domestic product (GDP). To examine the effect of FDI on GDP researcher has chosen D LOG GDP as a dependent variable and Independent variables are FDI. The output of 18 industries is the portion of GDP contributed by those industries. This enters into the analysis in absolute form. FDI maintains World Bank data. FDI is a part of the foreign investment (which excludes foreign aid and foreign portfolio investment). For the analysis, this study employs secondary data sources that consist of annual observation from the year 1987 to 2011 based on availability.

Dependent variable (LOG GDP): We can see that the LOG GDP (Figure 1) has an upward trend during our selected period from 1987-2011. We can see some ups and downs from 1987 to 1991 and after that, it was seen some sheer upward trends.

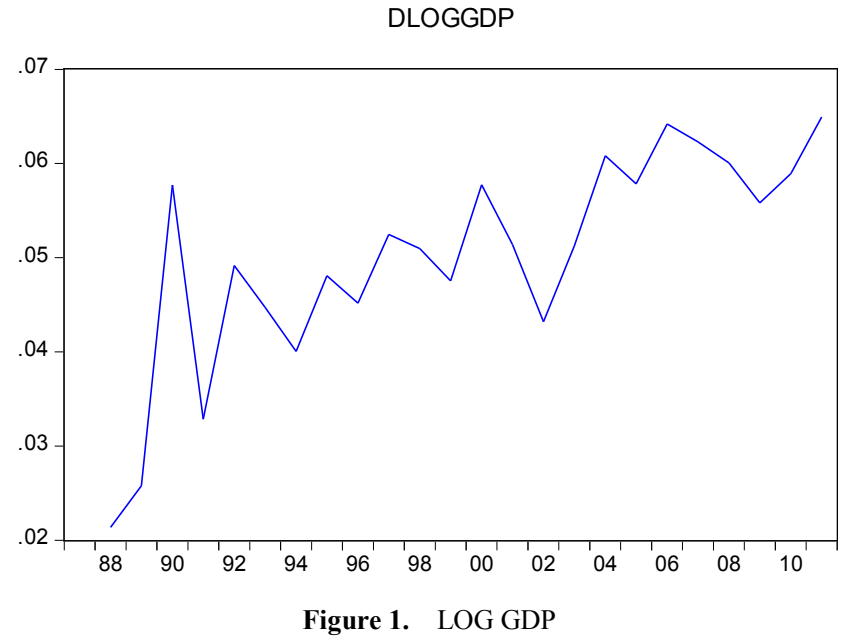

Independent variable: The FDI of Bangladesh was quite low from the year 1987 to 1995 (Figure 2); and after that, it was increased rapidly. After the year 2003 it was jumped all on a sudden and after that, it was more or less stable. The reason behind these fluctuations might be our overall economic condition which was increased after the later part of the nineties.

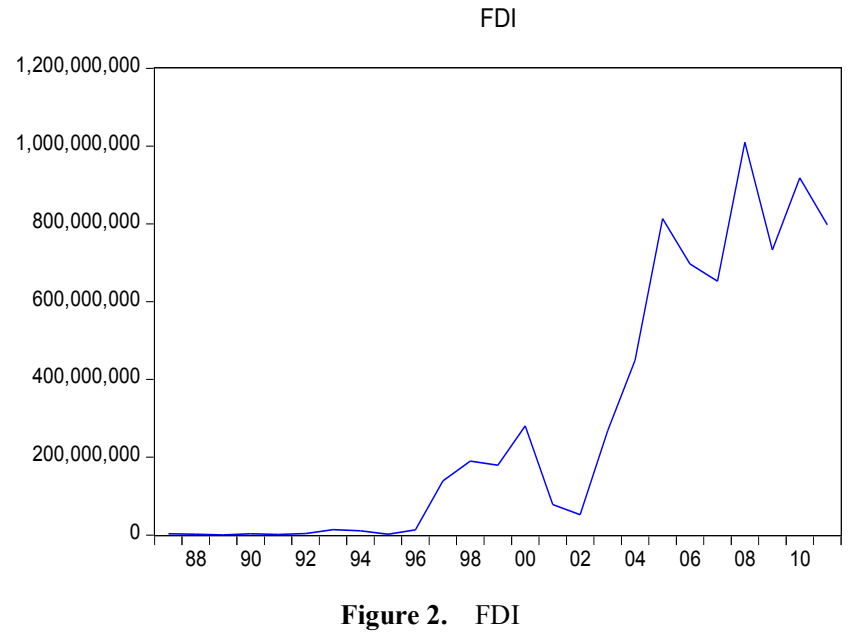


Research Question: This paper is based on some hypothesis for testing the causality and co-integration between LOG GDP and FDI in Bangladesh. The hypotheses taken for the consideration are given below.

(i) Examine bi-directional causality between LOG GDP and FDI

(ii) Is there unidirectional causality between the two variables?

(iii) Whether there is no causality between LOG GDP and FDI in Bangladesh

In this paper, researcher attempt to find the casual effects relationship between GDP growth and the foreign direct investment and co integration. The relationship can be expressed in the following manner:

$$
\mathrm{GDP}=\alpha+\beta_{1} \mathrm{fdi}+\mathrm{e}_{\mathrm{t}} .
$$

Here, GDP and FDI are the gross domestic product and growth of foreign direct investment respectively. Equation (1) is treated as an $\operatorname{AR}(1)$ model with foreign direct investment in Bangladesh, (FDI), as the only explanatory variable. If the test statistics will be less than critical value than we can reject $\mathrm{H}_{0}$ that is the series is non-stationary otherwise not. In this manner, I will taste two series.

After that, the researcher will try to find the long-run relationship between two series. For finding this, I attempt to describe cointegration analysis in the same manner

Here,

\section{$H_{0}:$ No Cointegration}

$\mathrm{H}_{1}:$ Cointegration

If the test statistics will be less than critical value than we can reject $\mathrm{H}_{0}$ that is the two series are cointegrated.

Result from Cointegration Test (Johansen Approach)

Table 1. ADF test to find cointegration

\begin{tabular}{|c|c|c|c|c|}
\hline \multicolumn{5}{|c|}{ Date: $13 / 09 / 15$ Time: $3: 47$} \\
\hline \multicolumn{5}{|c|}{ Sample (adjusted): 19902011} \\
\hline \multicolumn{5}{|c|}{ Included observations: 22 after adjustments } \\
\hline \multicolumn{5}{|c|}{ Trend assumption: Linear deterministic trend } \\
\hline \multicolumn{5}{|c|}{ Series: DLOGGDP FDI } \\
\hline \multicolumn{5}{|c|}{ Lags interval (in first differences): 1 to 1} \\
\hline \multicolumn{5}{|c|}{ Unrestricted Cointegration Rank Test (Trace) } \\
\hline Hypothesized & & Trace & 0.05 & \\
\hline No. of $\mathrm{CE}(\mathrm{s})$ & Eigenvalue & Statistic & Critical Value & Prob.** \\
\hline None * & 0.776519 & 33.13078 & 15.49471 & 0.0001 \\
\hline At most 1 & 0.007487 & 0.165337 & 3.841466 & 0.6843 \\
\hline \multicolumn{5}{|c|}{ Trace test indicates 1 cointegrating eqn(s) at the 0.05 level } \\
\hline \multicolumn{5}{|c|}{ * denotes rejection of the hypothesis at the 0.05 level } \\
\hline \multicolumn{5}{|c|}{ **MacKinnon-Haug-Michelis (1999) p-values } \\
\hline
\end{tabular}

Table 2. Results of the Cointegration

\begin{tabular}{|c|c|c|c|}
\hline Test Statistics & p-value & $5 \%$ critical value & Co integration \\
\hline 33.13078 & 0.0001 & 15.49471 & Yes \\
\hline
\end{tabular}

It is observed from the Table that-

- Here test statistics is less than the critical value so we can reject $\mathrm{H}_{\mathrm{o}}$ at $1 \%, 5 \%$ and also $10 \%$ critical value.

- So, both variables are cointegrated.
Cointegration test, reported in Table 1, indicates that both D LOGGDP and FDI series are cointegrated. The establishment of cointegration between the two series suggests that there exists no relation.

\section{Empirical Findings}

Table 3. Granger causality: D LOG GDP growth cause FDI

\begin{tabular}{|c|c|c|c|}
\hline \multicolumn{4}{|l|}{ Pairwise Granger Causality Tests } \\
\hline \multicolumn{4}{|l|}{ Date: Date: $13 / 09 / 15$ Time: $3: 48$} \\
\hline \multicolumn{4}{|l|}{ Sample: 19872011} \\
\hline \multicolumn{4}{|l|}{ Lags: 2} \\
\hline Null Hypothesis: & Obs & F-Statistic & Prob. \\
\hline FDI does not Granger Cause DLOGGDP & 22 & 8.92997 & 0.0022 \\
\hline DLOGGDP does not Granger Cause FDI & & 0.29499 & 0.7483 \\
\hline
\end{tabular}

Results of Granger causality Tests, reported in Table 3, shows we can reject the null hypothesis that the FDI does Granger-cause D LOGGDP, because the probability is low.

On the other hand, we cannot reject the null hypothesis that the coefficient of (FDI)' is equal to zero. Therefore, D LOGGDP does not Granger cause FDI because the probability is too high.

Most importantly, we also find the same result by testing Granger cause using VAR

$$
\mathrm{H}_{\mathrm{O}}=\text { var1 does not Granger cause var2 }
$$

The F-statistics suggest that the null hypothesis of uni-directional Granger causality cannot be rejected at a conventional level of significance. FDI\& D LOG GDP interacts each other in providing feedback but not showing any short-run relationship. The result also confirms that there is an uni-directional causality (feedback) between FDI \& D LOGGDP.

That is, Causality test indicates that there is a unidirectional causality from FDI to D LOG GDP in the case of Bangladesh. So, the conclusion is that, in Bangladesh, there is uni-directional long-run equilibrium relationship between FDI and D LOGGDP

\section{Discussion and Recommendations}

This paper tries to assess the relationship between foreign direct investment (FDI) and GDP in Bangladesh using annual data over the period 1987 to 2011. The unit root properties of the data were examined using the Augmented Dickey-Fuller test (ADF) after which the cointegration and causality tests were conducted. The major findings include the following -

- The unit root test clarified that both DLOG GDP and FDI are non-stationary at both level and the first differences in the case of Augmented Dickey-Fuller test (ADF). But, the series of both variables of our consideration-FDI and D LOGGDP, namely, foreign direct investment and $\log$ GDP were found to be 
integrated of order one using the ADF test for the unit root.

- The cointegration test confirmed that D LOG GDP and foreign direct investment are cointegrated, indicating the existence of long-run equilibrium relationship between the two as confirmed by the ADF cointegration test results.

On the basis of our findings, the major conclusion that can be drawn from the study is that Bangladesh is yet to fully reap the benefits of FDI, as its impact on growth at the moment is very little. However, hopes are the rifts that if round pegs are put in round holes, the anticipated benefits of FDI will begin to manifest in Bangladesh. We, therefore, recommend that the level of security at all levels in the country should be overhauled in order to boost indigenous private and foreign investors' confidence as instability in any nation scare away prospective investors. Furthermore, the foreign sector in Bangladesh should be liberalized, all barriers to trade that are inimical to cross- border trade such as arbitrary tariffs; import and export duties and other levies should be reduced to the bearest minimum or, if possible, removed. There should be a clear guideline in government policy regarding priority sectors that require foreign investments in Bangladesh among which sectors like agriculture and manufacturing should be uppermost for development. The spill-over effects of the development of these sectors would be the manifold increase in the rate of employment, GDP and output, food supply and raw materials for industries (especially local ones) and foreign exchange earning etc. Researchers' recommendations are given below ---

- A major shortage of power and electricity generation is a big obstacle for foreign investors here.

- Few labors skill generation institutions are here to full fill requirement of upcoming industries which is a factor of disinterest.

- Improper use of air, sea and river ports for export and import.

- Political instability in Bangladesh obsoletes the effect of FDI inflow.

- Slow development of infrastructure in the industrial zones.

- Weak international banking system to compete for international trades.

- Lack of the foresightedness of planning commission.

\section{Conclusions}

The role of FDI in this process is, by virtue of its impact on productivity and growth, to generate the resources needed to fund the government-led programs that improve social safety nets and provide basic social services. Moreover, the delivery of social services to the poor - from insurance schemes to access to basic services such as water and energy - can also benefit from reliance on foreign investors. It is thus imperative for the national governments to create the pre- conditions for FDI to flow in and work its wonders. A liberal and competitive investment climate creates the basis for FDI to enter and raise the potential for productivity growth in the host economy, but improvements will only occur if the domestic actors are capable of responding to the new incentives. The key policy measures are thus to improve the education and infrastructure so as to increase the domestic absorptive capacity of the fruits of FDI. For FDI to be a noteworthy provider to economic growth, India would do better by focusing on improving infrastructure, human resources, developing local entrepreneurship, creating a stable macroeconomic framework and conditions favorable for productive investments to augment the process of development.

It can not be said that FDI has a positive or negative impact on the economic growth of Bangladesh. The FDI inflows into Bangladesh are very low comparing to the other neighbor South Asian Countries. It is found that, FDI is positively correlated to the economic growth of Bangladesh, but it has not yet been established as a significant determining factor for the economic growth of Bangladesh. The estimated coefficient for FDI is positive but statistically insignificant. When the coefficient is insignificant, no inference can be drawn from the result of the used data set and the model. It can not be said that FDI has a positive or negative impact on economic growth. The result is ambiguous for Bangladesh and FDI has not been established as a significant determining factor for the economic growth of Bangladesh. The FDI policy should be formulated in such a way that causes attraction of more foreign potential direct investors and NRIs to invest in the country in those sectors which create employment and income on a larger scale.

\section{Appendix 1}

\begin{tabular}{|c|c|c|}
\hline YEAR & GDP & FDI \\
\hline 1987 & 26554115959 & 3205086.762 \\
\hline 1988 & 27127473044 & 1838242.499 \\
\hline 1989 & 27836138078 & 247908.2739 \\
\hline 1990 & 29489968538 & 3238781.189 \\
\hline 1991 & 30474743435 & 1390444.322 \\
\hline 1992 & 32010406325 & 3721853.382 \\
\hline 1993 & 33474682526 & 14049886.52 \\
\hline 1994 & 34842024065 & 11147788.33 \\
\hline 1995 & 36558011931 & 1896372.127 \\
\hline 1996 & 38247711533 & 13529831.54 \\
\hline 1997 & 40308326777 & 139376153.1 \\
\hline 1998 & 42415457211 & 190059373 \\
\hline 1999 & 44480763467 & 179662970.3 \\
\hline 2000 & 47124925462 & 280384629.7 \\
\hline 2001 & 49610300682 & 78527040.08 \\
\hline 2002 & 51800799317 & 52339473.35 \\
\hline 2003 & 54523446362 & 268285231.8 \\
\hline 2004 & 57942340648 & 448905400.7 \\
\hline 2005 & 61393084272 & 813321971.9 \\
\hline 2006 & 65463038830 & 697206284.1 \\
\hline 2007 & 69670899876 & 652818718.9 \\
\hline 2008 & 73983829245 & 1009623164 \\
\hline 2009 & 78231358239 & 732809635.6 \\
\hline 2010 & 82979485251 & 918172637.9 \\
\hline 2011 & 88545829824 & 797541178.9 \\
\hline
\end{tabular}




\section{REFERENCES}

[1] Mottaleb, K.A., (2007), Determinants of Foreign Direct Investment and Its Impact on Economic Growth in Developing Countries, MPRA Paper 9457, University Library of Munich.

[2] Borensztein, E. J., De Gregorio, and J.W.Lee. (1998). How Does Foreign Direct Investment After Economic Growth. Journal of International Economics, 34 (1), 115-135.

[3] Blomstrom, M., R.E. Lipsey and M. Zejan. (1996). What Explains Developing Country Growth. NBER Working paper No. 4132 (Cambridge, MA: NBER)

[4] Caves, R. (1996). Multinational and Economic Analysis, 2nd ed. Cambridge, MA: Cambridge University Press

[5] Carkovic, M. and R. Levine. (2002). Does Foreign Direct Investment Accelerate Economic Growth?, Working Paper (University of Minnesota Department of Finance, available at: $\mathrm{www} / / \mathrm{ssrn} . \mathrm{com} / \mathrm{abstract}=314924$ )

[6] Levine, R., N. Loayza, and T. Beck. (2000). Financial Intermediation and Growth: Causality and Causes. Journal of

Monetary Economics 46: 31-77

[7] Chowdhry, A. and G. Mavrotas. (2003). FDI and Growth: What Causes What. The World Economy, 29 (1), 42-58.

[8] Kholdy, Shady and Ahmad Sohrabian (2005). Financial Markets, FDI, and Economic Growth: Granger Causality Tests in Panel Data Model. EFA 2005 Moscow Meetings

[9] Hsiao, C. And Y Shen (2003), Foreign direct investment and economic growth: The importance of institution and urbanization. Econ. Dev. Cultural Change, 51: 883-896

[10] Choe, J.I. (2003), Do foreign direct investment and gross domestic investment promote economic growth?. Review of Development Economics, 7(1): 44-57.

[11] Nair-Reichert, U. and Weinhold, D. (2001). Causality Tests for Cross-Country Panels: New Look on FDI and Economic Growth in Developing Countries. Oxford Bulletin of Economics and Statistics, 63, 153-171

[12] Balasubramanyam, V. N., M. Salisu, and D. Sapsford (1999), Foreign Direct Investment as an Engine of Growth. Journal of International Trade and Economic Development, 8, 27-40.

[13] De Mello, L.R. (1997). Foreign Direct Investment in Developing Countries and Growth: A Selective Survey. Journal of Development Studies, 34 (1), 1-34. 